\title{
Research Square \\ Estimation of Milk Losses from Sub-Clinical Mastitis of Holstein-Zebu Cows Using a Nonlinear Exponential Decay Model
}

Epigmenio Castillo-Gallegos ( $\sim$ pime11302002@yahoo.com.mx )

Universidad Nacional Autónoma de México https://orcid.org/0000-0002-2850-9795

Martín Cordero-Montoya

Universidad Nacional Autónoma de México

Miguel Ángel Alonso-Díaz

Universidad Nacional Autonoma de Mexico

\section{Research Article}

Keywords: nonlinear models, subclinical mastitis, grazing cows, tropics, dairy, income

Posted Date: October 25th, 2021

DOI: https://doi.org/10.21203/rs.3.rs-985210/v1

License: (c) (1) This work is licensed under a Creative Commons Attribution 4.0 International License.

Read Full License 
Estimation of milk losses from sub-clinical mastitis of Holstein-Zebu cows using a nonlinear exponential decay model.

${ }^{1}$ Centro de Enseñanza, Investigación y Extensión en Ganadería Tropical, Facultad de Medicina, Veterinaria y Zootecnia, Universidad Nacional Autónoma de México. Carretera Federal 129 Amozoc-Nautla, km 5.5 tramo Martínez de la TorreTlapacoyan, Municipio de Tlapacoyan, Veracruz, 93600, México.

${ }^{2}$ Private practice, cattle health and production. Ezequiel Montes, Querétaro, México.

* Corresponding author. Email: epigmeniocastillo@ comunidad.unam.mx. Tel. (Office): +52 2323243941 ext. 127.

Abstract

11 We fitted a one-phase exponential decay function (primary term) to the relationship between the sum of the CMT scores of productive quarters (SCMT, 0 to 16) and daily milk production per cow (MPC, kg/day). We added the multiplicative factors test day (T, 1 to 12), days in milk (D, 2 to 196), months of age of cow (A, 25 to 209), and the number of productive quarts (Q,

141 to 4 ) to the model to adjust the primary term for their effects. We calculated a conversion factor (CF, 0 to 1$)$ from the primary 15 term as a quotient between the predicted MPC at the i-th SCMT divided by the predicted MPC at SCMT=0. The calculated 16 projected MPC was that of the cow as if it were SCM-free. We obtained it by dividing the observed MPC on test day by the 17 CF. The difference between the projected and observed MPC was milk loss multiplied by MX $\$ 5.50$ (US\$ 0.275), which gave economic loss. The model was: MPC $=\left[(7.60-4.68) \mathrm{e}^{-0.1773 \mathrm{SCMT}}+4.68\right]\left(\mathrm{T}^{-0.0791}\right)\left(\mathrm{D}^{-0.1701}\right)\left(\mathrm{A}^{0.1855}\right)\left(\mathrm{Q}^{0.1835}\right)$ with an $\mathrm{R}^{2}$ of 0.3975 .

19 The average cow had an SCMT=6, T=7, D=75, A=79, and $\mathrm{Q}=4$. The predicted MPC at SCMT=0 was $9.1 \mathrm{~kg} / \mathrm{cow}$, and at $20 \mathrm{SCMT}=6$ it was $6.8 \mathrm{~kg} / \mathrm{cow}$; the $\mathrm{CF}=6.8 / 9.1=0.7484$. The observed MPC on test day was $5.8 \mathrm{~kg} / \mathrm{day}$; then, the projected $21 \mathrm{MPC}$ at $\mathrm{SCMT}=0$ is $5.8 / 0.7484=7.7 \mathrm{~kg} /$ day. Then, milk loss is $7.7-5.8=1.9$, and economic loss is MX $\$ 10.72 /$ day. It was 22 straightforward to devise and implement this type of calculation of milk and economic losses.

23 Keywords: nonlinear models, subclinical mastitis, grazing cows, tropics, dairy, income.

24 Introduction

Subclinical mastitis (SCM) is an udder infection that does not show external signs of the disease like inflammation 26 and is caused mainly by bacteria that negatively affect milk yield and quality (Ávila-García \& Mena, 2015). The prevalence of 27 SCM is high under the hot and humid conditions of tropical regions. For example, research conducted in the same production 28 unit with the same type of cattle and management by González-Sedano et al. (2010) found that at the quarter level of overall 
29 prevalence of SCM was between $37.9 \%$ and 59.5\% for residual calf suckling once after milking and no residual calf suckling, respectively. The situation prevails in most dual-purpose tropical dairies of México (Pech-Martínez et al., 2007) and other countries with hot and humid environments, like India, where a meta-analysis conducted by Krishnamoorty et al. (2017), found a pooled prevalence value was $42 \%$.

Most tropical dairy farmers usually do not know that subclinical mastitis presents a much higher frequency than the clinical form (Mungube et al., 2005). The quarter with SCM does not show clinical signs. Therefore, the farmer assumes the udder is healthy and does not take action to mend the situation by improving the milking process hygiene, which leads to reductions in milk yield and quality, negatively affecting the economic income of the farm. So, specific detection methods such as the California Mastitis Test must help avoid the milk yield and financial losses associated with SCM (De Graaf \& Dwinger, 1996; Iraghua et al., 2017).

Schalm \& Noorlander (1957) devised the California mastitis test (CMT), and it has become the "animal-aside" diagnostic assay more frequently used to monitor subclinical mastitis in dairy herds. The basis for this test is the lysis of somatic cells by the CMT reagent to precipitate the DNA and proteins contained in the cells. Consequently, the development of a change in viscosity of the reagent when added to milk is directly related to the relative number of somatic cells. Based on the viscosity change, the sample can be semiquantitatively scored to allow for sample comparison and facilitate communication of the severity (Plummer \& Plummer, 2012). The degree of SCM uses a five-point scale, namely, negative, traces,,,+++ and,+++ that correspond to original average somatic cell counts of 100,000,320,000,950,000, 2'900,000, and 5'000,000 cells, respectively. If the effects of all other factors remain constant, the SCM infected udder will produce less milk than the same udder but under healthy conditions. Then, milk production decreases as the CMT score increases (Janzen, 1970). However, the relationship varies from a decreasing straight line (Tesfaye et al., 2010) to a convex negative-decay (Mungube et al., 2005).

50 Both linear and nonlinear models summarize information needed to understand biological phenomena like growth or lactation.

51 Developing a model that describes the milk production response pattern to subclinical udder infections within a particular 52 environment and management system helps determine the importance of factors affecting production efficiency. The fitting of 53 a linear function to the milk production-CMT score relation has received little attention from dairy scientists. Fitting linear and 54 nonlinear functions to this relationship would help describe the course of the disease smoothly and estimate the amount and 55 rate at which losses in milk production per cow and herd occur as SCM changes. In addition, analysis of the curves helps 56 identify preventive medicine problems that lead to strategic changes to improve production efficiency. 
We proposed that a mathematical relationship between subclinical mastitis, measured by the California mastitis test, and milk production could be the basis for milk production loss computation. Therefore, the objective of the present study was

59 to determine the fit of the monophasic exponential decay function to the CMT score-milk production per cow data as a part of 60 a protocol for milk loss evaluations due to SCM in this herd.

\section{$61 \quad$ Materials and methods}

\section{Location}

The study took place at the Centro de Enseñanza, Investigación y Extensión en Ganadería Tropical (Center for 64 Education, Research, and Extension in Tropical Animal Science - CEIEGT in Spanish), Facultad de Medicina, Veterinaria y 65 Zootecnia, Universidad Nacional Autónoma de México, from 26 May to 19 August 2017 (84 days). Its location on the Gulf of 66 México coastal plains lies about $40 \mathrm{~km}$ west of the coastline. Its geographical coordinates are $20^{\circ} 02^{\prime}$ of northern latitude, $97^{\circ}$ 6706 ' of western longitude, and 112 masl of altitude. The climate is hot and humid without a defined dry season. Minimum and 68 maximum average temperatures are $18.6 \pm 3.9^{\circ} \mathrm{C}$, and $29.2 \pm 3.3^{\circ} \mathrm{C}$, respectively. The yearly rainfall mean is $1931 \mathrm{~mm}$ with 69 a standard deviation of $334 \mathrm{~mm}$. Three climatic seasons occur: rainy from July to October, with high precipitation and 70 temperature; winter or "norther-wind" from November to February, with lower rainfall and temperatures; and dry from March 71 to June (Castillo et al., 2005). The high temperature and the increased air and soil moisture that prevails throughout the year 72 favor mastitis-causing bacteria growth.

\section{Cattle management}

The present investigation used eighty-four lactating cows of different ages and lactation days. The animals grazed rotationally, pastures composed of a mixture of exotic (Urochloa brizantha, Urochloa arrecta, Cynodon nlmefuensis), and native grasses (Axonopus spp, Paspalum spp). The cows were machine milked once a day between 8:00 and 10:00 AM, and milk production registered in $\mathrm{kg} / \mathrm{cow} / \mathrm{day}$. The supplement was one kilogram of commercial concentrate (88\% dry matter, $18 \%$ crude protein) and a mineral mixture fed ad libitum at milking time. The calves did not suckle; thus, the cows received an

79 intradermic oxytocin injection of 10 IU within a minute and a half before milking to facilitate milk let-down.

\section{Description of data}

The application of the CMT to the milking herd took place on twelve occasions from 26 may to august 19 of 2017.

83 (SCMT) of the four quarters was the independent variable. The number of quarters with CMT score evaluations was 2748. Of

84 those, 2076 were from 63 cows with their four quarters intact, 568 corresponded to 17 cows with three functional quarters, and 
85104 evaluations belonged to four cows with only two-quarters available. The distribution numbers of CMT scores were 1183, $86586,409,379$, and 184 for $0,1,2,3$, and 4, respectively. There were twelve test days (T). At the trial start, the cows were from

872 to 196 days in milk (D), their ages (A) varied from 25 to 209 months, and 2, 3, or 4 functional quarters (Q).

\section{Statistical analysis}

We used a multiplicative model to control a one-phase exponential decay curve to study the relationship between daily milk production per cow (MPC) and the SCMT score. Multiplicative models are repeated measures designs in which milk

91 production is represented as any relationship, linear or nonlinear. Its effects, the error term included, are multiplicative, proportional to the magnitude of MPC. The models may consist of longitudinal factors, those that act over the entire curve, like

93 the cow, and perpendicular effects, which change the curve pattern at a particular time, like a month, season, etc. (Menchaca 94 et al., 1996).

The monophasic exponential decay function was the primary term (in bold) in the following model:

$$
\mathrm{y}=\left((\mathbf{a}-\mathbf{b}) \mathbf{e}^{-\mathbf{c 1} 1 \text { SCMT }}+\mathbf{b}\right)\left(\mathrm{T}^{\mathrm{c} 2}\right)\left(\mathrm{D}^{\mathrm{c} 3}\right)\left(\mathrm{A}^{\mathrm{c} 4}\right)\left(\mathrm{Q}^{\mathrm{c} 5}\right) .
$$

97 Where y is the average milk production per cow on the week previous to the test, test day included. Parameters a and $\mathrm{b}$ are the 98 amounts of milk produced by a cow with an SCMT score of 0 and a cow scored 16 , respectively. The (a $-\mathrm{b})$ component is the 99 extent of milk loss. The parameter $\mathrm{c} 1$ is a relative decay rate expressed as $\mathrm{kg}$ of milk loss per kg produced per unit increase in 100 SCMT. Parameters c2, c3, c4, and c5, were power coefficients for the remaining variables T, D, A, and Q, respectively. The 101 model was solved by the iterative procedure of Marquardt using PROC NLIN (SAS, 2013). The extra sum of squares F-ratio 102 test helped identify non-significant terms (Motulsky and Christopolous, 2003)., except the primary function.

\section{Economic losses}

The estimated milk loss (ML) was the difference between $\mathrm{y}_{\mathrm{xpct}}$ or expected milk production at $\mathrm{x}=0$, and $\mathrm{y}_{\mathrm{obs}}$ or the observed milk production on the test week. In turn, the $\mathrm{y}_{\mathrm{xpct}}$ value came from the product of $\mathrm{y}_{\mathrm{obs}}$. and a theoretical conversion factor $\left(0 \leq \mathrm{CF} \leq 1\right.$, unitless), calculated from the monophasic exponential decay parameters as $C F=\hat{y}_{(0)} / \hat{y}_{(0 \leq x \leq 16)}$, where the 107 numerator is the predicted milk production at SCMT score of zero $\left(\hat{y}_{(0)}\right)$ and the denominator is the predicted milk production 108 at each $\mathrm{x}$ value $\left(\hat{y}_{(4 \leq x \leq 365.2)}\right)$. The economic loss was the milk loss multiplied by the price per $\mathrm{kg}$ of milk at the farm's gate, 109 currently 5.50 pesos or 0.275 dollars per kilo of milk, given an exchange rate of 20.00 Mexican pesos per US dollar.

\section{Results}


Table 1 shows the descriptive statistics for milk production per cow, according to the value of SCMT. The means of

112 MPC declined as SCMT increased. The MPC data was highly variable since CV ranged from $29 \%$ to $54 \%$, with an overall 113 value of $51 \%$.

Table 2 presents the analysis of variance for the decay function alone or the complete model that included the multiplicative terms. Both models were highly significant $(\mathrm{P}<0.0001)$. Figure 1 shows that the coefficient of determination of the decay function alone was low because of the high variability of the milk production data and other factors. The inclusion of the multiplicative terms improved fit 3.5 times compared to the decay function (adjusted coefficients of determination of 0 . significantly ( $\mathrm{P}=0.0310$ and $\mathrm{P}=0.0436$, respectively), while the days in milk and age of cow increased highly significantly $(\mathrm{P}<<0.0001)$, the sum of squares of the model. Even though $\mathrm{T}$ and $\mathrm{Q}$ were significant, they only contributed to the overall adjusted coefficient of determination (0.3975) with 0.0038 and 0.0034 fraction units, respectively, that is, less than $1 \%$ in either case. The cause of their significance was, no doubt, the large number of degrees of freedom for the residual variation.

Table 4 presents the parameters of the decay function without the control multiplicative variables (second column) and that of the model with all four control variables included (last column). The values of parameter a differed significantly between both models (11.6342 vs. $7.6043, \mathrm{P}=0.0127)$. On the other hand, the $\mathrm{b}$ parameters difference showed a tendency to be significant (7.0261 vs. 4.6823, $\mathrm{P}=0.0733)$. Even though the $\mathrm{c} 1$ parameter difference among both models appeared noticeable (0.2924 vs. 0.1773$)$, it was not significant $(\mathrm{P}=0.3123)$. On the other hand, the parameters $\mathrm{c} 2$ and $\mathrm{c} 3$ were negative, so milk production per cow decreased as the test days advanced and the days in milk increased. On the contrary, c4 and c5 were positive, so milk production increased with age and number of quarters.

Table 5 presents the computation of the factors used to convert the observed $y_{i}$ to the expected maximum $y_{\max }$. The decay function extracted from the multiplicative model served to compute a predicted $\mathrm{y}$ per each $\mathrm{x}$ value. The conversion factor increased with SCMT, e. g. for SCMT $=0, \hat{y}=7.60$, the conversion factor was 7.60/7.60 $=1$. For $\mathrm{SCMT}=8, \hat{y}=5.39$, and the $\mathrm{CF}=5.39 / 7.60=0.7088$.

Table 6 presents the milk and money loss for the cow 201-4 on test weeks 4, 8, and 12. That cow started the present study with 130 days in milk and 36 months of age. The daily milk loss varied from 1.2 to $2.1 \mathrm{~kg} / \mathrm{day}$, equivalent to MX\$ 6.60 


\section{Discussion}

Some published papers present plots of the CMT score vs. milk yield. Still, so far, we found only one in which the

141 researchers used a simple linear regression to relate milk production to the degree of subclinical mastitis, assessed with electrical

142 conductivity (Oshima et al., 1990). In our case, we selected the monophasic exponential decay function because the original

143 relationship between somatic cell counts (SCC) and CMT scores (Schalm \& Noorlander, 1957) has the shape of an exponential

144 growth equation. If the relationship between SCC and milk production is negative, then the relationship among SCMT scores

145 and MPC had to be a negative exponential decay function. Furthermore, the decay function presented the best fit over simple

146 linear regression and the Cobb-Douglass power function (data not shown).

147 Figure 1 shows a wide amplitude of the standard deviations, which led to a low coefficient of determination (0.11),

148 considered inadequate for prediction purposes. Nevertheless, the 95\% confidence bands of the fitted function indicate that the

149 likely location of the fitted line is pretty narrow, suggesting that it is the more likely model. The multiplicative terms inclusion

150 improved the fit (Table 2), modifying the magnitude of the response of milk production to the SCMT scores per cow (Figure

151 2). The extra sum-of-squares F-ratio test analysis indicated a significant effect of the control factors added to the model, and

152 for this reason, the final model included them (Table 4).

The exponential decay curve convexity depended on parameter $\mathrm{c} 1$, an instantaneous relative rate of decrease of milk

154 production as SCMT scores increase. So if $\mathrm{c} 1$ changes for any reason, so does convexity. The c1 parameter is a relative rate

155 that indicates the $\mathrm{kg}$ of milk loss per $\mathrm{kg}$ of milk produced as the SCMT score changes one unit. Figure 2 demonstrates that the

156 multiplying factors increased the curve's height when averages and medians were used to predict the MPC of the average cow 157 for this herd.

158 Our data showed an increasing milk production curve in response to age. The many old cows in our herd remained in 159 it because of their well above average milk production and reproduction performance, increasing the milk production values 160 for advanced ages. On the other hand, the daily milk production response to advancing age or parity of Holstein cows under 161 intensive management is parabolic (Yoon et al., 2004). The animals of the present study did not show the typical milk 162 production-age relationship because we only collected partial lactation data. Nonetheless, the age effect was highly significant 163 ( $\mathrm{P}<0.0001)$, and its inclusion improved model fit, so it fulfilled its purpose.

164 Menchaca (1970) developed and applied multiplicative models to describe biological processes like cattle and pasture 165 growth and lactation curves. The model consists of a primary function, preferable an exponential for ease of linearization 166 adjusted (“controlled") for by the power-effect of different factors known to modify the behavior of the biological process 
described by the chosen function. The logarithmic conversion of the multiplicative model into its additive form allows applying formal analysis of variance procedures for parameter estimation. We used an iterative approach to estimate the parameters of nonlinear regression functions because it was not necessary to comply with unusual assumptions like the side conditions mentioned by (Menchaca et al., 1996). Besides, the decay function is easy to fit by conventional software (SAS, 2013), and its parameters have practical meaning. production of quarters scored negative in the CMT or a very low SCC. After that, the expression of milk loss is a fraction or percentage that increases with the CMT score (Janzen, 1970).

De Graaf and Dwinger (1996), in five farms situated on the cloud forest ecological zone of Alajuela and Heredia provinces of Costa Rica, paired 200 cows with subclinical mastitis with another 200 healthy cows based on breed, lactation number, and days in milk. The loss in milk production was the difference between the milk produced by the healthy cow minus the milk produced by the cow with SCM. The unadjusted production loss of a cow with SCM was $1.56 \mathrm{~kg} / \mathrm{cow} / \mathrm{day}$, equivalent to $17.6 \%$ of the milk produced by healthy cows. This case-control study allowed these researchers a great control of residual variation. However, pairing needs numerous cows, a resource not readily available if the research occurs in small farms. Otherwise, these types of experiments would need more extended periods.

$\mathrm{DPMQ}=\mathrm{DRMQ} *(\mathrm{TQ} /(\mathrm{TQ}-\mathrm{UQE}))$, where: $\mathrm{DPQM}$ is daily potential milk production per quarter, DRMQ is daily actual milk production per quarter, TQ is the total number of quarters, and $\mathrm{UQE}$ is the unproductive quarter equivalence. The same authors estimated the $\mathrm{UQE}$ as follows: $\mathrm{UQE}=\mathrm{TQ} *((1 * \mathrm{PLQ})+(0.02 * \mathrm{PLSQ})+(0.33 * \mathrm{PHSQ})$, where: PLQ is the prevalence of lost quarters per farm, PLSQ is the prevalence of low SCC quarters (250-1000 x $10^{3}$ cells per ml), PHSQ is the prevalence of high SCC (> $1000 \times 10^{3}$ cells per ml). The advantage of using this formula is that it takes into account production losses due to unproductive quarters. But on the other hand, the coefficients 1.00, 0.02, and 0.33 came from animals managed in different environments and management conditions (Mungube et al., 2005), so its use may not be appropriate because it may lead to biased estimation of milk loss.

We fitted a nonlinear regression function to predict the effect of subclinical mastitis on individual milk production and compute milk loss factors from it (Table 5). Our fractional conversion factors (CF) were divisors that converted the 
194 computation approach was different. However, it is the same basis: the difference between the milk produced by an SCM-free 195 quarter minus the milk produced by an SCM-affected quart.

196 Shaw and Beam (1935) were probably the first to refer to the opposite quart procedure to study milk loss due to SCM, 197 and after them and up to the present time, several authors followed (Forster et al., 1967; Janzen, 1970; Romero et al., 2018). 198 Most studies measure and express milk loss on a per quarter basis because in the same udder, a quarter may be healthy while 199 others may present SCM. The opposite quarter measurement technique obeys the purpose of having a case (the quarter with 200 SCM) and control (the quart without SCM) within the same animal, improving error control. Individual quarters produce 201 different amounts of milk when healthy and react differently to SCM (Jansen, 1970). Another reason for using opposite quarters 202 is to consider the negative influence of non-functional quarters on milk production. The trends of SCM incidence obtained in 203 some studies point out that the incidence rate of SCM in different quarters is not similar, being higher in hindquarters (Pranay 204 et al., 2017). However, when the milk production recording is on a per cow basis, it is not easy to justify the division by four 205 to calculate milk production per quarter; because the differences between the front and rear quarters are unaccounted for in the 206 computation. Estimating total herd milk yield loss varies with cow-level SCC and parity distribution within the herd, so it is 207 necessary to calculate milk loss per cow basis (Chen et al., 2020). These were the reasons behind our use of the sum of all CMT 208 scores as an explanatory variable when registered milk per cow is the response variable.

\section{Conclusions}

210 It was feasible to fit a negative exponential decay function to describe the milk production-CMT score relationship 211 and calculate conversion factors to project test-day milk production of a cow with SCM into milk production of a healthy cow. 212 Then, to estimate milk loss by difference. There are many variations in the environmental landscape of the tropics that would 213 lead to differences in the milk loss in response to differences in the CMT scores, so it is advisable to use local nonlinear 214 regression functions to avoid biased evaluations. Incorporating the calculation procedure into an electronic worksheet is pretty 215 straightforward, making possible a timely and on-site estimation of milk loss.

216 The somatic cell counts must be more accurate than the CMT score to predict milk losses because its basis is 217 quantitative and objective. At the same time, that of the CMT is qualitative and subjective, thus prone to biases and significant 218 variations. Nevertheless, in some situations like in tropical México, measuring the SCC is expensive, and there is a lack of 219 adequately trained personnel to perform this task. So, the CMT must be the procedure of choice to test for subclinical mastitis 220 for the time being. Besides, considering the economic losses generated by subclinical mastitis in the herd, extension agents and 221 practitioners must constantly alert dairy farmers about the negative consequences of not testing cows for subclinical mastitis. 
Supplementary information We do not provide supplemental information.

Acknowledgments The funds to conduct this research were from the current budget of the Universidad Nacional Autónoma 224 de México, exerted through the Faculty of Veterinary Medicine and Animal Science at its Center for Tropical Animal Production.

Author contribution Epigmenio Castillo-Gallegos conceived the study, did the statistical analysis and interpretation and wrote the draft. Miguel Cordero-Montoya did the CMT and milk production measurements and reviewed the document as well.

Miguel Angel Alonso-Díaz conceived and designed the study and reviewed the draft.

229 Data availability Databases are available upon reasonable request.

230 Code availability SAS codes are available upon reasonable request.

\section{Declarations}

Ethics approval The management of cattle followed applicable national and international guidelines for the care, use, and 233 production.

234 Consent to participate All authors agreed on their roles and participation tasks and also on the authorship.

235 Consent for publication All authors agreed on the publication of the manuscript.

236 Conflict of interest The authors declare not to have any conflict of interest.

\section{References}

238 Ávila, J. and Mena, T. 2015. Glándula Mamaria. En: Mena, T. (comp), Bienestar Bovino. Buenas prácticas sanitarias y manejo integral de producción [Bovine well being. Sanitary and integral production management good practice], (Bayer, México)

Chen, H., Weersink, A., Kelton, D., and von Massow, M. 2021. Estimating milk loss based on somatic cell count at the cow

Castillo, G.E., Valles, M., B.V., Aluja, S.A. 2005. Efecto de introducir Arachis pintoi sobre variables del suelo de pasturas de grama nativa del trópico húmedo mexicano. Técnica Pecuaria en México, 43(2), 287-295

245 De Graaf, T., Dwinger, R. H. 1996. Estimation of milk production losses due to subclinical mastitis in dairy cattle in Costa Rica. Preventive Veterinary Medicine, 26, 215-222

Forster, T. L., Ashworth, U. S., and Luedecke, L. O. 1967. Relationship between California Mastitis Test reaction and production and composition of milk from opposite quarters. Journal of Dairy Science, 50, 675-682 
González-Sedano, M., Marin-Mejia, B., and Maranto, M. I., Leme De Magalhaes-Labarthe, A.C., and Alonso-Díaz MA. 2010. Effect of residual calf suckling on clinical and sub-clinical infections of mastitis in dual-purpose cows: epidemiological measurements. Research in Veterinary Science, 89, 362-366

Iraguha, B., Hamudikuwanda, H., Mushonga, B., Kandiwa, E., and Mpatswenumugabo, J. P. 2017. Comparison of cow-side diagnostic tests for subclinical mastitis of dairy cows in Musanze district, Rwanda. Journal of the African Veterinary Association, 88:11-16

Janzen, J. J. 1970. Economic losses resulting from mastitis. A review. Journal of Dairy Science, 53, 1151-1160

Krishnamoorthy, P., Suresh, K. P., Saha, S., Govindaraj, G., Shome, B. R., and Roy, P. 2017. Meta-analysis of prevalence of subclinical and clinical mastitis, major mastitis pathogens in dairy cattle in India, International Journal of Current

Menchaca, M. A. 1978. Modelo multiplicativo con efecto de curva de lactancia controlado para el análisis estadístico con

Menchaca, M. A., Chase Jr, C. C., Olson, T. A., and Hammond, A. C. 1996. Evaluation of growth curves of Brahman cattle of various frame sizes. Journal of Animal Science, 74, 2140-2151 vacas lecheras [Multiplicative model with controlled lactation curve effect for the statistical analysis with dairy cows] (Unpublished PhD thesis, Instituto de Ciencia Animal, La Habana, Cuba).

Oshima, M., Yoshida, T., Koyama, K., \& Moriyama, T. (1990). A method for assessing loss in milk yield due to subclinical

Pech, M. V. C. P., Carvajal, H. M. C., y Montes, P. R. M. 2007. Impacto económico de la mastitis subclínica en hatos bovinos de doble propósito de la zona centro del estado de Yucatán. Tropical and Subtropical Agroecosystems, 7 , $127-131$ (eds), Sheep and Goat Medicine (Elsevier, Amsterdam), 442-465 
276 Pranay, B., and Champak, B. (2017). Interdependence and distribution of subclinical mastitis and intra-mammary infection 277 among udder quarters in Jersey crossbred cows. International Journal of Agriculture Sciences, 9, 4235-4237

278 Romero, J., Benavides, E., and Meza, C. 2018. Assessing financial impacts of subclinical mastitis on Colombian dairy farms. $279 \quad$ Frontiers in Veterinary Science, 5, 273-283

280 SAS Institute Inc. 2013. SAS/STAT ${ }^{\circledR} 12.3$ User’s Guide. (SAS Institute Inc., Cary, NC)

281 Schalm O. W., and Noorlander D. O. 1957. Events and experiences leading to the development of the California Mastitis Test (CMT), Journal of the American Veterinary Medical Association, 130, 199-209

283 Shaw, A. O., and Beam., A. L. 1935. Effect of mastitis upon milk production. Journal of Dairy Science, 18:353-357

284 Tesfaye, G. Y., Regassa, F. G., and Kelay, B. 2010. Milk yield and associated economic losses in quarters with subclinical 285 mastitis due to Staphylococcus aureus in Ethiopian crossbred dairy cows. Tropical Animal Health and Production, 42, 925-931

287 Yoon, J. T., Lee, J. H., Kim, C. K., Chung, Y. C., and Kim, C. H. (2004). Effects of milk production, season, parity and lactation 288 period on variations of milk urea nitrogen concentration and milk components of Holstein dairy cows. AsianAustralasian Journal of Animal Sciences, 17, 479-484 
Table 1. Descriptive statistics for milk production of grazing F1 Holstein-Zebu cows according to the sum CMT scores from the four quarters (SCMT).

\begin{tabular}{cccccccc}
\hline \multirow{2}{*}{ SCMT } & \multicolumn{7}{c}{ Statistics of daily milk production per cow } \\
\cline { 2 - 7 } & $\mathrm{n}$ & Mean & Std. Dev. & Std. Error & C. V. & LB95 & UB95 \\
\hline 0 & 146 & 11.68 & 5.11 & 0.42 & 43.78 & 10.84 & 12.52 \\
1 & 59 & 10.05 & 5.27 & 0.69 & 52.41 & 8.68 & 11.43 \\
2 & 82 & 10.11 & 5.11 & 0.56 & 50.49 & 8.99 & 11.24 \\
3 & 85 & 8.75 & 4.39 & 0.48 & 50.15 & 7.81 & 9.70 \\
4 & 72 & 7.78 & 4.01 & 0.47 & 51.53 & 6.84 & 8.72 \\
5 & 53 & 8.74 & 3.83 & 0.53 & 43.75 & 7.69 & 9.80 \\
6 & 48 & 7.70 & 4.19 & 0.61 & 54.45 & 6.48 & 8.92 \\
7 & 33 & 8.03 & 3.95 & 0.69 & 49.24 & 6.63 & 9.43 \\
8 & 44 & 7.78 & 3.48 & 0.52 & 44.70 & 6.72 & 8.83 \\
9 & 30 & 7.21 & 2.72 & 0.50 & 37.66 & 6.20 & 8.23 \\
10 & 27 & 7.06 & 3.31 & 0.64 & 46.85 & 5.75 & 8.37 \\
11 & 18 & 7.96 & 3.92 & 0.92 & 49.23 & 6.01 & 9.91 \\
12 & 10 & 7.79 & 2.25 & 0.71 & 28.88 & 6.18 & 9.40 \\
13 & 21 & 6.10 & 2.69 & 0.59 & 44.07 & 4.88 & 7.33 \\
14 & 8 & 6.20 & 3.97 & 1.41 & 64.10 & 2.88 & 9.52 \\
15 & 1 & 8.00 & ----- & ---- & ---- & ----- & ---- \\
16 & 3 & 7.93 & 3.05 & 1.76 & 38.45 & 0.36 & 15.51 \\
Overall & 740 & 9.07 & 4.64 & 0.17 & 51.22 & 8.73 & 9.40 \\
\hline
\end{tabular}


Table 2. Analysis of variance of the multiplicative model with the control of the one-phase exponential decay curve. Both models described the relationship between the California mastitis test score upon milk production of F1 Holstein-Zebu cows.

\begin{tabular}{|c|c|c|c|c|c|c|c|}
\hline Source & $\mathrm{DF}^{1}$ & SS & MS & F value & $\operatorname{Pr}>\mathrm{F}$ & $\mathrm{R}_{\text {adj. }}^{2}$ & RSD \\
\hline \multicolumn{8}{|c|}{ Monophasic exponential decay function (primary function) } \\
\hline Model & 3 & 1832.40 & 610.80 & 31.87 & $2.2560 \mathrm{E}-19$ & 0.1150 & 4.38 \\
\hline Residual & 736 & 14107.39 & 19.17 & & & & \\
\hline Total & 739 & 15939.79 & 21.57 & & & & \\
\hline \multicolumn{8}{|c|}{ Multiplicative with control of the primary function } \\
\hline Model & 7 & 6336.18 & 905.17 & 68.99 & $2.2779 \mathrm{E}-76$ & 0.3975 & 3.62 \\
\hline Residual & 732 & 9603.61 & 13.12 & & & & \\
\hline Total & 739 & 15939.79 & 21.57 & & & & \\
\hline
\end{tabular}

$301{ }^{1}$ The headings meaning are DF, degrees of freedom; SS, sums of squares; MS, mean square; $\mathrm{R}^{2}$ adj., coefficient of 302 determination adjusted by parameter number, and RSD, residual standard deviation. 
307 Table 3. An extra sum of squares F ratio test was used to identify non-significant factors in the multiplicative model.

308

\begin{tabular}{|c|c|c|c|c|c|c|c|c|}
\hline Source of variation ${ }^{1}$ & $\begin{array}{l}\text { Degrees of } \\
\text { freedom }\end{array}$ & $\begin{array}{c}\text { SS of the } \\
\text { model }\end{array}$ & Extra $\mathrm{SS}^{2}$ & $\begin{array}{c}\text { MS of the } \\
\text { model }\end{array}$ & Extra MS & F ratio & $\operatorname{Pr}>\mathrm{F}$ & Partial $\mathrm{R}^{2}$ \\
\hline SCMT & 3 & 1832.40 & & 610.80 & & 46.56 & $<0.0001$ & 0.1150 \\
\hline SCMT, T & 1 & 1893.69 & 61.29 & & 61.29 & 4.67 & 0.0310 & 0.0038 \\
\hline SCMT, T, D & 1 & 5870.01 & 3976.32 & & 3976.32 & 303.08 & $<0.0001$ & 0.2495 \\
\hline $\mathrm{SCMT}, \mathrm{T}, \mathrm{D}, \mathrm{A}$ & 1 & 6282.58 & 412.57 & & 412.57 & 31.45 & $<0.0001$ & 0.0259 \\
\hline SCMT, T, D, A, Q & 1 & 6336.18 & 53.60 & & 53.60 & 4.09 & 0.0436 & 0.0034 \\
\hline Error & 732 & 9603.61 & & 13.12 & 13.12 & & & \\
\hline Corrected total & 739 & 15939.79 & & & & & & $0.3975^{2}$ \\
\hline
\end{tabular}

$309{ }^{1}$ SCMT, sum of the four quarters CMT scores; T, mean test days; D, days in milk at start; A, age of cows at start in months; Q, number of functional quarters.

$3102^{2}$ Extra SS is the marginal increase in the model resulting from the sequential addition of another variable to the model.

$311{ }^{3}$ It is the coefficient of determination of the full model (SCMT, T, D, A, Q). 
Table 4. Parameters of the multiplicative model with the control of the monophasic exponential decay curve. In cursive, the 95\% lower and upper limits of the parameters.

\begin{tabular}{|c|c|c|c|c|c|}
\hline \multirow{2}{*}{ Parameter } & \multirow{2}{*}{$\mathrm{SCMT}^{1}$} & \multicolumn{4}{|c|}{ SCMT PLUS ${ }^{1}:$} \\
\hline & & $\mathrm{T}$ & $\mathrm{T}, \mathrm{D}$ & $\mathrm{T}, \mathrm{D}, \mathrm{A}$ & $\mathrm{T}, \mathrm{D}, \mathrm{A}, \mathrm{Q}$ \\
\hline \multirow[b]{2}{*}{$\mathrm{a}$} & 11.6342 & 10.6444 & 20.7043 & 10.3031 & 7.6043 \\
\hline & 10.9616 to 12.3068 & 9.3679 to 11.9209 & 18.1816 to 23.2271 & 7.4954 to 13.1109 & 4.4967 to 10.712 \\
\hline \multirow{2}{*}{$\mathrm{b}$} & 7.0261 & 6.4758 & 14.3010 & 6.4750 & 4.6823 \\
\hline & 6.0353 to 8.017 & 5.379 to 7.5727 & 10.3164 to 18.2856 & 4.0527 to 8.8973 & 2.3086 to 7.0559 \\
\hline \multirow{2}{*}{$\mathrm{c} 1$} & 0.2924 & 0.2964 & 0.1707 & 0.1857 & 0.1773 \\
\hline & 0.1198 to 0.465 & 0.1205 to 0.4723 & -0.0202 to 0.3615 & 0.0373 to 0.3341 & 0.0354 to 0.3192 \\
\hline \multirow{2}{*}{$\mathrm{c} 2$} & 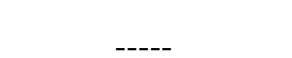 & 0.0480 & -0.0789 & -0.0804 & -0.0791 \\
\hline & & -0.0079 to 0.1040 & -0.1275 to -0.0302 & -0.1280 to -0.0328 & -0.1266 to -0.0317 \\
\hline $\mathrm{c} 3$ & ----- & ----- & $\begin{array}{c}-0.1751 \\
-0.1969 \text { to }-0.1533\end{array}$ & $\begin{array}{c}-0.1742 \\
-0.1954 \text { to }-0.1531\end{array}$ & $\begin{array}{c}-0.1701 \\
-0.1915 \text { to }-0.1487\end{array}$ \\
\hline $\mathrm{c} 4$ & ----- & ----- & ----- & $\begin{array}{c}0.1732 \\
0.1124 \text { to } 0.2341\end{array}$ & $\begin{array}{c}0.1855 \\
0.1235 \text { to } 0.2474 \\
0.1835\end{array}$ \\
\hline $\mathrm{c} 5$ & ----- & ----- & ----- & ----- & 0.0019 to 0.3652 \\
\hline
\end{tabular}

${ }^{1}$ SCMT, sum of the four quarters CMT scores; T, mean number of test days; D, days in milk at start; A, age of cows at start in months; Q, number of functional quarters. 
336 Table 5. Conversion factor computed from the monophasic exponential decay function: $337 \quad \widehat{M P C}_{\mathrm{i}}=(7.60-4.68) \mathrm{e}^{-0.1773 * S C M T_{\mathrm{i}}}+4.68$. 338

\begin{tabular}{cccc}
\hline $\mathrm{SCMT}^{1}$ & $\widehat{\mathrm{MPC}}_{\mathrm{i}}$ & $\widehat{\mathrm{MPC}}_{0}$ & $\begin{array}{c}\text { Conversion factor } \\
\widehat{\mathrm{MPC}}_{\mathrm{i}} / \widehat{\mathrm{MPC}}_{0}\end{array}$ \\
\hline 0 & 7.60 & 7.60 & 1.0000 \\
1 & 7.13 & ------ & 0.9376 \\
2 & 6.73 & ----- & 0.8853 \\
3 & 6.40 & ----- & 0.8415 \\
4 & 6.12 & ----- & 0.8048 \\
5 & 5.88 & ----- & 0.7741 \\
6 & 5.69 & ------ & 0.7484 \\
7 & 5.52 & ------ & 0.7269 \\
8 & 5.39 & ------ & 0.7088 \\
9 & 5.27 & ------ & 0.6937 \\
10 & 5.18 & ----- & 0.6810 \\
11 & 5.10 & ----- & 0.6704 \\
12 & 5.03 & ------ & 0.6616 \\
14 & 4.97 & ------ & 0.6541 \\
15 & 4.92 & ------ & 0.6479 \\
\hline
\end{tabular}

${ }^{1}$ SCMT is the sum of CMT scores of the productive quarters of the udder. 
342 Table 6. Estimated milk production and economic losses due to the subclinical mastitis of the cow 201-4 on test 343 days 4,8 , and 12 . The y variable is the average daily milk production of the cow on the week preceding the test, 344 test day included.

345

\begin{tabular}{ccccccc}
\hline Test day & SCMT $^{1}$ & CF & Observed MPC ${ }^{2}$ & $\begin{array}{c}\text { Expected MPC } \\
\text { at SCMT }=0^{3}\end{array}$ & $\begin{array}{c}\text { Milk Loss } \\
\text { per day }\end{array}$ & $\begin{array}{c}\text { MX\$ loss } \\
\text { per day }\end{array}$ \\
\hline 4 & 8 & 0.7088 & 5.0 & 7.1 & 2.1 & 11.55 \\
8 & 5 & 0.7741 & 4.1 & 5.3 & 1.2 & 6.60 \\
12 & 7 & 0.7269 & 3.9 & 5.4 & 1.5 & 8.25 \\
\hline
\end{tabular}

$346{ }^{1}$ SCMT is the sum of the CMT scores from all productive quarters.

$347{ }^{2}$ The observed MPC is the average milk production on the week previous to the test.

$348{ }^{3}$ The expected MPC at SCMT=0 is equal to the observed test day MPC divided by the conversion factor (CF).

$349{ }^{4}$ Milk loss is the difference between the expected MPCat SCMT $=0$ and observed MPC on the test day.

3505 The price of milk at the farm's gate was MX $\$ 5.50$ (US\$ 0.275. MX\$20.00 per US dollar. 
Figures

$$
\begin{gathered}
y_{i}=(11.63-7.03)^{\star} e^{-0.2924^{*} x i}+7.03 \\
R_{\text {adj. }}^{2}=0.1126, \text { RMSR }=4.38, \text { Residual } D F=737
\end{gathered}
$$
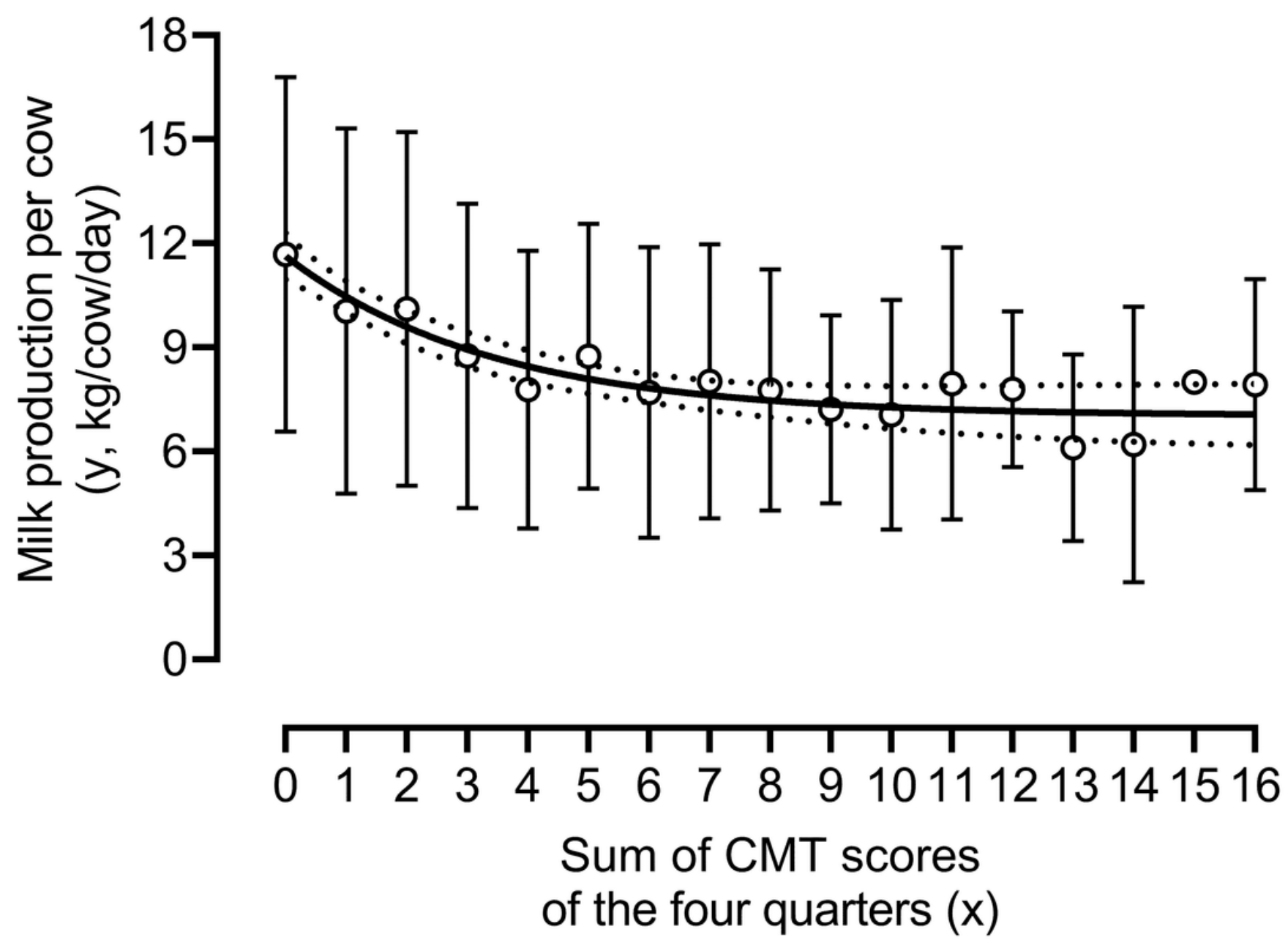

Figure 1

Monophasic exponential decay relationship between observed daily milk production per cow (MPC, $\mathrm{kg} / \mathrm{cow} /$ day) and the sum of the CMT scores of the four quarters (SCMT) of grazing F1 Holstein-Zebu cows. The solid line is the fitted function, and the dotted lines are the $95 \%$ confidence bands showing the likely location of the actual curve. R2adj. is the coefficient of determination adjusted for the number of parameters in the model; RMSR is the square root of the mean square of the residual, and DF is degrees of freedom. 


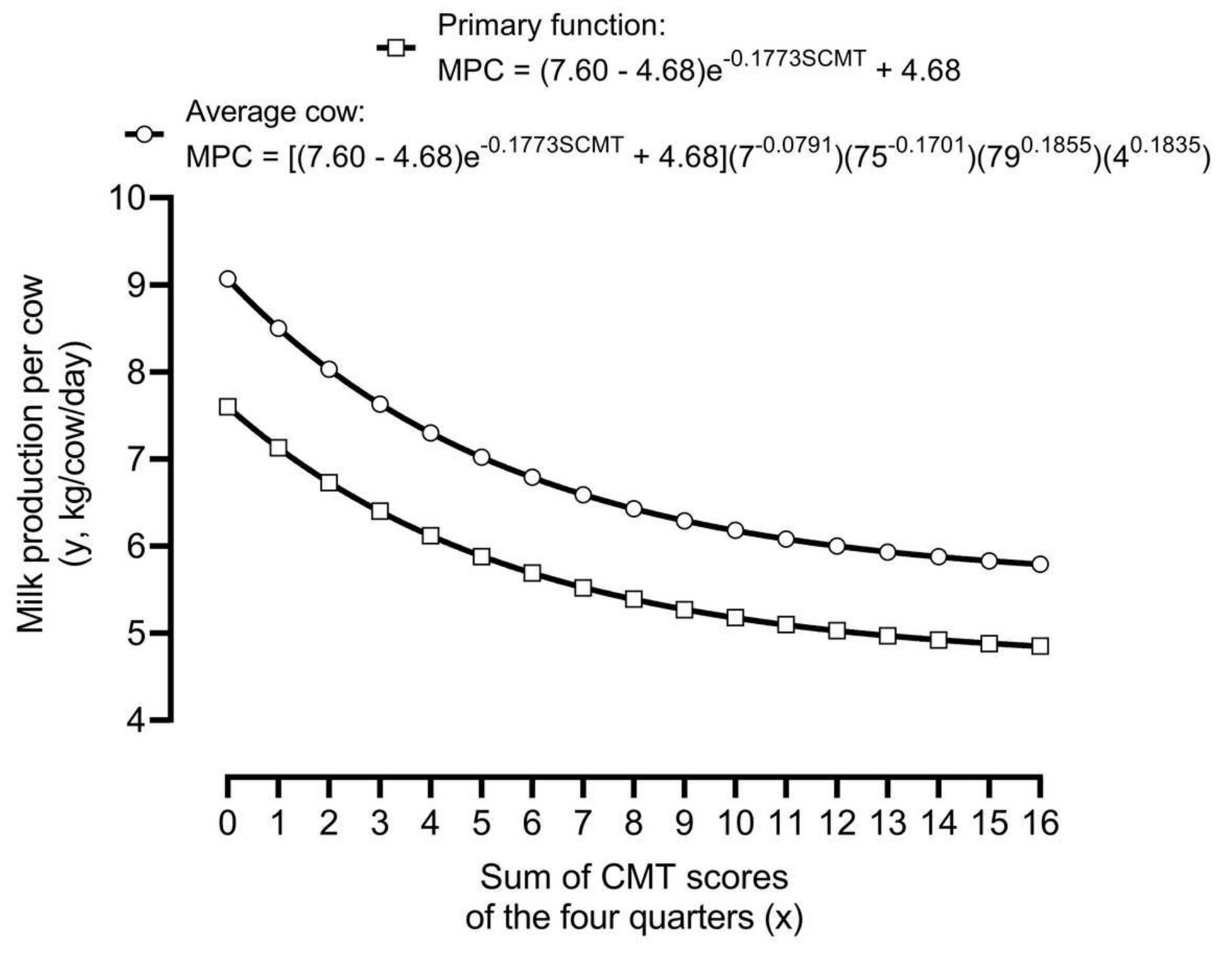

Figure 2

Effect of the sum of the CMT (SCMT) scores of the productive quarters on milk production per cow (MPC; $\mathrm{kg} /$ day). The primary function does not have any of the control factors and gives unadjusted milk production values. The equation for the average cow had as control factors that modify the height of the curve, the averages for days in milk (D, 75) and age of cow ( 79 months), and the medians for test day $(T, 7)$ and the number of productive quarters $(\mathrm{Q}$, four $)$. 